\title{
ว

\section{Utilization of Narrow Land with Verticulture Techniques in Urban Area}

\author{
Rudi Hartono*, Kansih Sri Hartini, Agus Purwoko \\ Faculty of Forestry, Universitas Sumatera Utara, Medan, Indonesia, 20155
}

\begin{abstract}
Urban areas are generally in the form of housing with narrow land. The purpose of this activities was to use narrow land for farming with verticulture techniques. The activity was held in Puri Zahara 1 Residence, Medan Tuntungan District. which is a residential area with narrow land. The method used was to provide training to housewife to be able to utilize the land with verticulture techniques. Housewives was briefed in order to be able to use the land using existing materials, especially verticulture techniques. The material used in verticulture techniques was paralon. The result of this dedication is that the community can utilize small land, especially in residential areas with verticulture techniques to plant flowers or vegetable crops, so that the house becomes greener and livelier. With this verticulture technique, more vegetable or fruit crops can be planted. some plants planted include lettuce, water spinach, flowers.
\end{abstract}

Keywords: Narrow land, Urban area, Vertikuculture technique

\begin{abstract}
Abstrak. Daerah perkotaan pada umumnya berupa perumahan dengan lahan sempit. Tujuan pengabdian ini adalah memanfaatkan lahan sempit untuk bercocok tanam dengan teknik vertikultur. Kegiatan dilaksanakan di Kompleks Puri Zahara 1, Kecamatan Medan Tuntungan. yang merupakan daerah perumahan dengan lahan sempit. Metode yang dilakukan adalah dengan memberikan pelatihan kepada ibu-ibu komplek agar mampu pemanfaatkan lahan yang dengan teknik vertikultur. Ibu-ibu rumah tangga diberi pengarahan agar bisa memanfaatkan lahan dengan memanfaatkan bahan yang ada, terutama teknik vertikultur. Bahan yang digunakan dalam teknik vertikultur adalah paralon. Hasil dari pengabdian ini adalah masyarakat bisa memanfaatkan lahan kecil, khususnya di wilayah perumahan dengan teknik vertikultur menanam bunga atau tanaman sayur-sayuran, sehingga rumah menjadi lebih hijau dan semarak. Dengan teknik vertikultur ini, lebih banyak
\end{abstract}

*Corresponding author at: Faculty of Forestry, Universitas Sumatera Utara, Medan, Indonesia

E-mail address: rudihartono@usu.ac.id 
tanaman sayuran atau buah yang dapat ditanam. Beberapa tanaman yang di tanam antara lain selada, kangkung dan bunga.

Kata Kunci: Lahan sempit, Perkotaan, Teknik vertikultur

Received 9 January 2021 | Revised 19 January 2021 | Accepted 28 May 2021

\section{Introduction}

Indonesia is a country that has an area of $1,904,569 \mathrm{~km}^{2}$ with the $4^{\text {th }}$ most population in the world after China, India and America. The population density in Indonesia reaches $255,993,674$ people (around 255 million) or about $3.5 \%$ of the total world population. Population density in Indonesia is concentrated in urban areas with a percentage reaching $53.3 \%$ in 2015 and is predicted to continue to increase to $66 \%$ in 2035 [1].

Increasing the population number in urban areas has an impact on housing needs. In fulfill these needs, so many people make agricultural land and forests used as housing or shelter. Agricultural land has been turned into housing. Existing agricultural land can no longer contribute to Indonesian agriculture. That resulted in declining agricultural output.

Many efforts to reduce the decline in agricultural output, such as verticulture method [2]. This technology can optimize land use [2]. This method has been applied to grow vegetables such as shallots [3], red spinach [4] mustard greens, kale, spinach, lettuce, and celery [5]. So that with this method, people in urban areas with limited land can grow vegetables, so that the needs of vegetables can be provided by the community themselves, and if professionally managed it will be able to become a business land or food crop business in urban areas.

Therefore, the narrow land can be used for farming. One way to do this is by verticulture methods. Plants that are planted can be in the form of vegetables and flowers. The purpose of this service is to use narrow land for farming with verticulture techniques.

\section{Methods}

Dedication was carried out in the Komplek Puri Zahara I, Medan Tuntungan District. Community service activities carried out include (Figure 2).

a. Socialization of verticultural method.

b. Explain to make verticulture method by using the PVC.

- Provide PVC with a diameter of 3 inches and length of $1.5 \mathrm{~m}$.

- The top of the PVC is opened about $4 \mathrm{~cm}$ using a grinder to place soil and plants. 


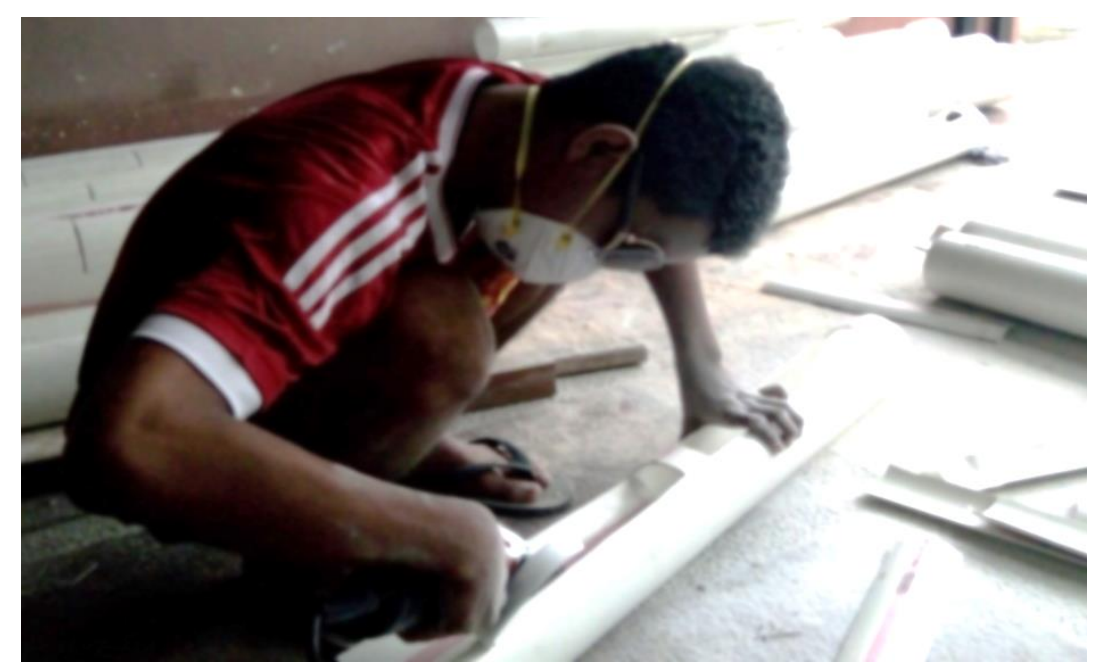

Figure 1. Make verticulture using PVC

- Make a small hole at the bottom of the PVC to drain excess water

- Place the PVC vertically

a. The practice of planting flowers and vegetables.

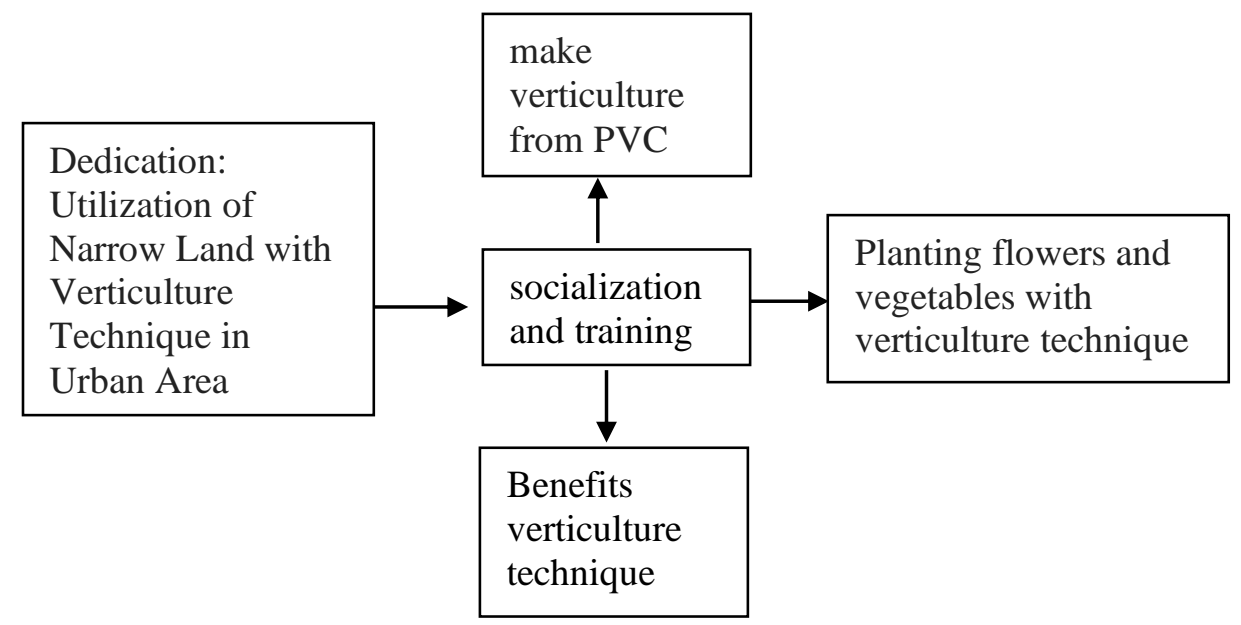

Figure 2. Approach method scheme

\section{Results and Discussion}

Counseling activities and demonstration for utilization the narrow land for flowers and vegetables using a verticulture methods which was carried out by involving the residents of Puri Zahara 1 residence, Medan Tuntungan district. Based on observations prior to the implementation and demonstration, it seems that almost no yard is planted with vegetables. The dominant plants in Puri Zahara Housing are ornamental plants or flowers.

In general, Housewives in Puri Zahara 1 residence do not yet know that vegetables can be planted verticulture methods made from waste materials such as waste pipes. Housewives used to plant flowers in her yard using pots. 
They argue that plant the vegetables and flowers require a large area and is not possible to do in a limited yard. Whereas the verticulture method is a greening concept that is suitable for urban area with narrow land. This method can be applied in densely populated areas, because it does not require large area. This method can use a variety of simple or optimize parts of house yard [6].

Verticulture methods have advantages and disadvantages. Some advantages of this method are: (a) efficiency in land use (b) efficient use of fertilizers and pesticides, (c) less likely to grow grass and weeds, (d) can be moved easily, (e) easy monitoring/ maintenance of plants, (f) the presence of a plastic roof prevents damage due to rain, $(\mathrm{g})$ saves watering costs because plastic roofs reduce evaporation [3].

In this service activity was done the evaluation. The purpose of this evaluation was to see the active participation of the housewives participating in counseling and demonstration activities and also the results of the demonstration. Active participation of housewives in counseling activities can be seen from the percentage of attendance, discussion atmosphere and participation during demonstrations (Figure 3). Based on the attendance list, housewives attended $90 \%$ from the invitation list.
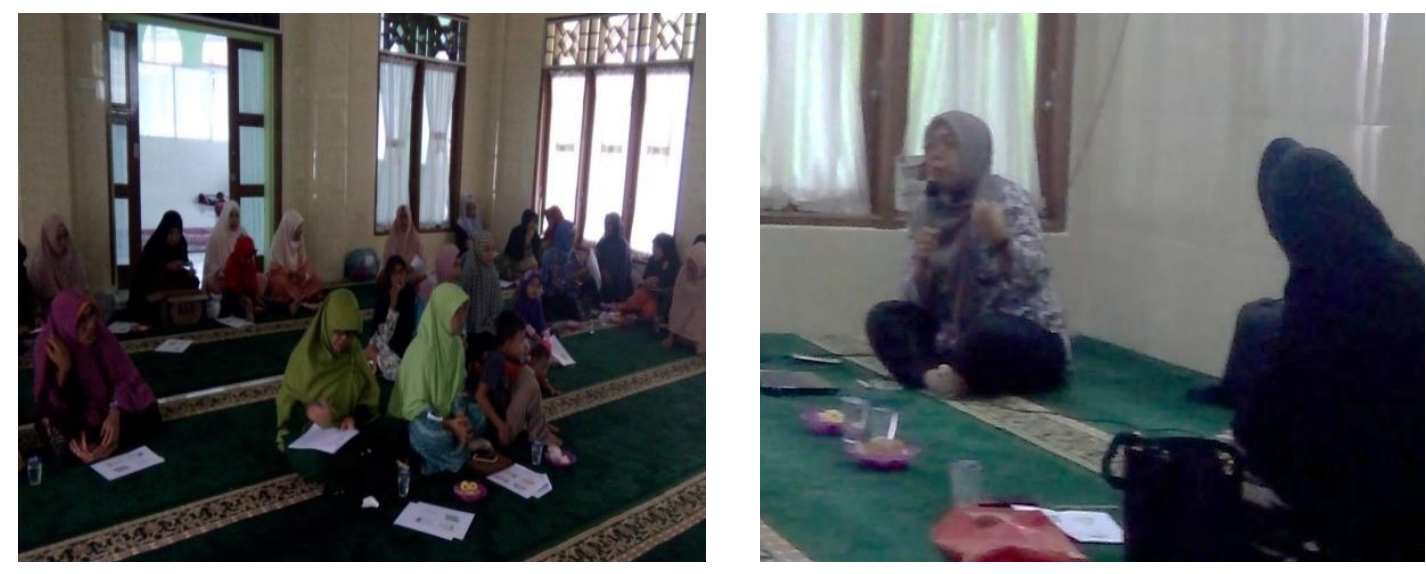

Figure 3. Socialization of community service

Positive responses were shown by the housewives during the socialization and demonstration activities. This positive response can be seen from many housewives who ask questions related to the verticulture method and participate in demonstrations. Most housewives participated in growing flowers in verticultural containers (Figure 4). The positive response shown by housewives is a measure of the high desire of participants to understand and carry out the verticulture methods. 

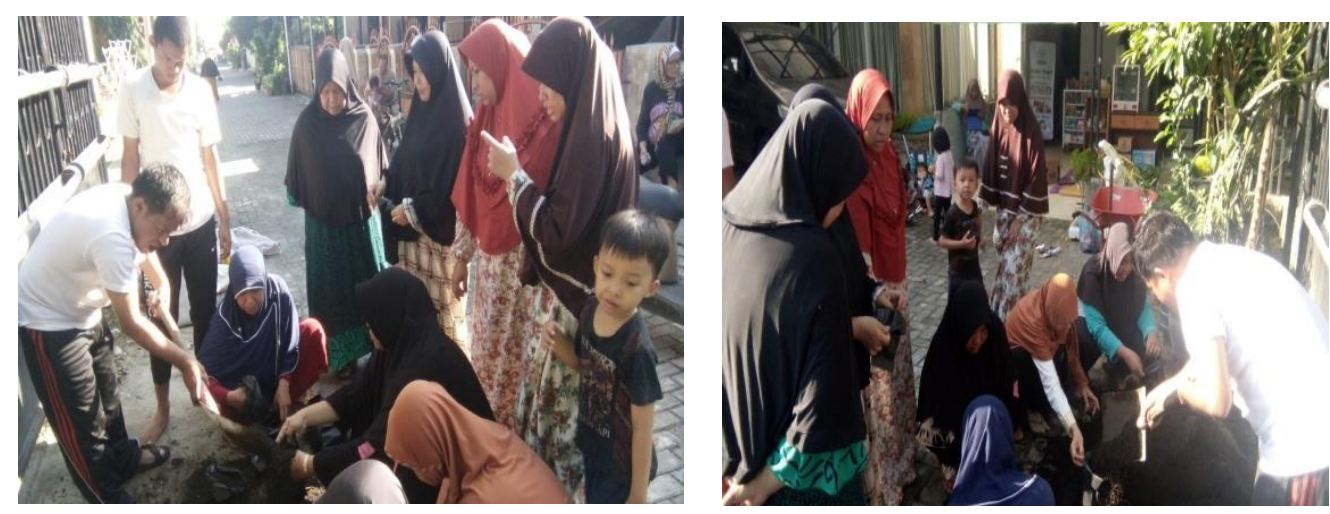

Figure 4. Active housewives in planting demonstrations

After 2 months of community service activities, shown that seedlings planted such as water spinach and flowers grow well. Plants that grow with verticulture technique can beautify the house (Figure 5). This means that people in urban areas with limited land can grow various kinds of plants such as vegetables and flowers. Vegetables grown can be harvested and eaten. If this is done in housing with narrow land using the vertical method, the number of vegetables planted will be more and this can reduce the costs used to buy vegetables.

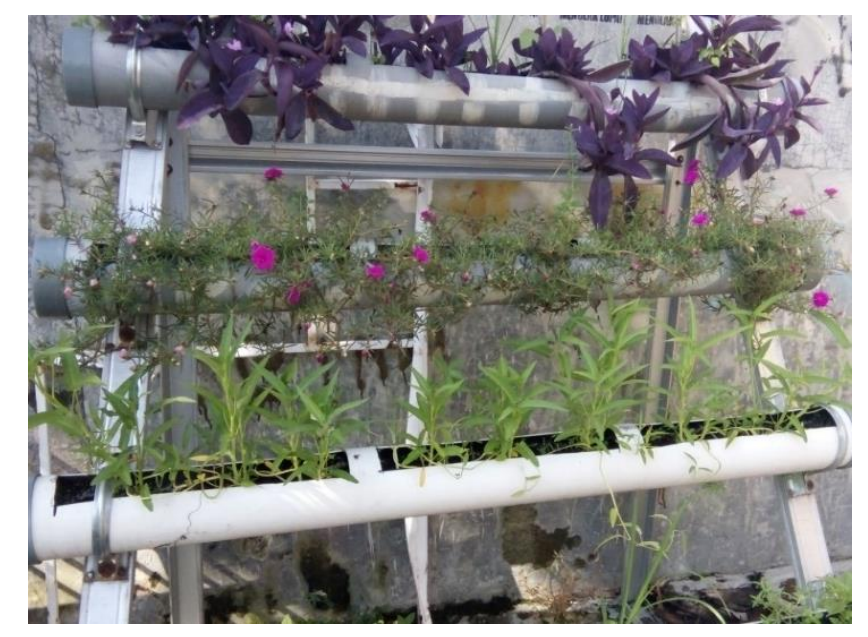

Figure 5. Planting results with verticulture technique

\section{Conclusions}

The motivation of housewives increases to take advantage of the narrow yard area by planting various type of flowers and vegetable. The verticulture method is very suitable for planting at the narrow yard, because with the verticulture method, more plants can be planted and the quality can be improved by fertilization. 


\section{Acknowledgement}

The acknowledgement delivered to Community Service Institution of Universitas Sumatera Utara. The support was under the grant number: 172/UN.5.2.3.2.1/PPM/2018 on April $16^{\text {th }} 2018$.

\section{References}

[1] Statistical Yearbook of Indonesia. Statistic Indonesia, Jakarta, 2015.

[2] I.W. Werdhany, "Land saving technology by vertikulture system." Agricultural Technology Reseach Center, Yogyakarta, 2012.

[3] Pujiati, D.R. Sari, C.N. Primmiani, "Onion Verticulture." Study program of Biology Educatioin, Faculty of Teacher Training and Education, University of PGRI, Madiun, 2017.

[4] D.S.O. Yosandi, M. Baskara, N. Herlina, "The Effect of Planting Media in Verticulture System on Growth and Yield of Red Spinach (Amaranthus tricolor)." Journal of Plant production. Vol 6: 20, pp 10-16, 2018.

[5] G.M. Ningsih, H. Rasyid, Muhidin, "Cultivation of Vegetable Crop by Verticulture Method." Proceeding of Nasional seminar and product exhibition. University of Muhammadiyah Malang. pp 333-339, 2016.

[6] R.N. Sesanti, Sismanto, H. Hidayat, N.S.P. Nuryanti, S. Handayani, "Organic vegetable cultivation with a vertical system effort to increase resident income at housing of Sejahtera Hajimena, South Lampung." Journal of development economic. Vol 2 (4): 369-381, 2012. 